\title{
OBSERVATIONS ON THE BLOOD OF WORKMEN EXPOSED TO HIGH TEMPERATURES ${ }^{1,2}$
}

\author{
By PAUL L. McLAIN AND EDWARD S. MONTGOMERY \\ (From the Department of Physiology and Pharmacology, University of Pittsburgh, Pittsburgh)
}

(Received for publication February 28, 1938)

The morbidity arising from exposure of workmen to excessively high environmental temperatures is an old problem, extended and accentuated by the development of modern industry. Economic and humanitarian motives have combined, in recent years, to stimulate investigation of the various clinical entities grouped under the general term " heat sickness." Of the many contributions on this problem, those of Hall and Wakefield (1), Bock and Dill (2), Talbott and Michelsen (3), Heilman and Montgomery (4), and Talbott (5) are particularly enlightening. The last author supplies an extensive bibliography. Both clinical and laboratory studies point to derangement of salt, sugar, and water metabolism as possible factors in the production of heat sickness.

The present study amplifies the observations of Heilman and Montgomery (4) on the blood of steel workers. The blood findings of a control group were compared with those of patients exhibiting symptoms due to heat. Some technical modifications and additional observations necessitated an entirely new control series. The work occupied the summer months of 1936 and 1937.

\section{CLINICAL MATERIAL AND PROCEDURE}

The control group consisted of 43 workmen whose occupation involved daily exposure to conditions under which heat sickness is likely to develop. The subjects were aged 26 to 58 years, the average being 41 years. The average height was 69 inches, with extremes at 64 and 75 inches. The weights were from 125 to 234 pounds, averaging about 173 pounds. The controls were, at the time of examination, clinically free of any

1 This investigation was supported by a grant from the Bindley Fund, The School of Medicine, University of Pittsburgh.

2 Clinical material and laboratory facilities were provided by the Allegheny Steel Company, Brackenridge, $\mathrm{Pa}$. Some additional patients were supplied by the Clairton Works of the Carnegie-Illinois Steel Corporation, Clairton, $\mathrm{Pa}$. symptoms attributable to heat. No restrictions as to diet or fluid intake were imposed, since average working conditions were desired. Blood samples were drawn, in each instance, before the subjects reported for work and at the end of an eight-hour shift. The post-work samples were used for comparison with blood findings in victims of heat sickness.

The group of patients comprised 30 workmen admitted to the Emergency Hospital for relief of heat symptoms. These patients were classified clinically as victims of heat cramps (17 cases), heat exhaustion (6 cases), and heat retention or "stroke" (7 cases). The criteria for such classification are outlined by Heilman and Montgomery (4). Blood samples were obtained from the patients prior to treatment and studied in the same manner as those of controls. In addition, control samples were obtained from 16 of the patients when they were symptom-free.

\section{MEASUREMENTS AND METHODS}

The following measurements were made, chiefly on samples of venous blood defibrinated by gentle stirring. Great care was exercised to avoid rough treatment during defibrination. In all cases, the blood after defibrination retained its venous hue.

Red and white cell counts were made in duplicate or triplicate, the most consistent results being averaged.

Hemoglobin concentration was estimated in the majority of instances by the Haden-Hausser apparatus (clinical model). In some cases, the Sahli instrument was employed. All values were expressed as grams of hemoglobin per $100 \mathrm{cc}$. of blood.

Percentage volume of red cells was measured on undiluted blood by means of a power hematocrit, driven at high speed until the columns of sediment showed no further shrinkage.

Specific gravity was measured by Guthrie's (6) modification of the Barbour and Hamilton "falling-drop method" (7). 
Blood sugar was estimated by the improved (macro) method of Folin and $\mathrm{Wu}(8)$, using filtrates prepared from unlaked blood.

Serum chloride was measured by the method of Whitehorn (9), and the results expressed in terms of $\mathrm{Cl}$.

Carbon dioxide combining power of citrated plasma was measured by the volumetric method of Van Slyke (10).

Serum calcium was estimated by Collip's modification of the Kramer-Tisdall method (11).

\section{RESULTS AND DISCUSSION}

\section{The blood in normal workmen}

Blood findings in the control group are summarized in Table I. For each series of determina-

TABLE I

Summary of blood findings in workmen exposed to high temperatures; controls

\begin{tabular}{|c|c|c|c|c|c|c|c|c|}
\hline \multirow{2}{*}{ Observation } & \multicolumn{2}{|c|}{ Maximum } & \multicolumn{2}{|c|}{ Minimum } & \multicolumn{2}{|c|}{ A verage } & \multicolumn{2}{|c|}{$\begin{array}{l}\text { Standard } \\
\text { deviation }\end{array}$} \\
\hline & A.M. & P.M. & A.M. & P.M. & A.M. & P.M. & A.M. & P.M. \\
\hline 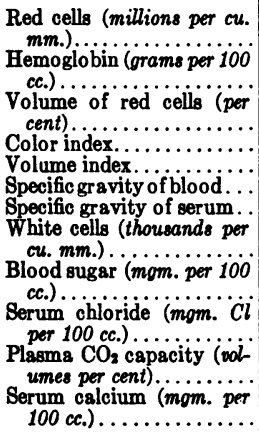 & $\begin{array}{l}5.920 \\
16.1 \\
51.0 \\
1.19 \\
1.24 \\
1.060 \\
1.030 \\
10.2 \\
137 \\
406 \\
76 \\
11.0\end{array}$ & \begin{tabular}{|l|}
6.320 \\
16.4 \\
50.5 \\
1.24 \\
1.31 \\
1.063 \\
1.036 \\
9.8 \\
118 \\
422 \\
68 \\
11.0
\end{tabular} & $\begin{array}{l}4.200 \\
13.0 \\
41.5 \\
0.85 \\
0.87 \\
1.050 \\
1.021 \\
6.2 \\
47 \\
334 \\
51 \\
9.8\end{array}$ & $\begin{array}{l}4.000 \\
11.9 \\
40.0 \\
0.82 \\
0.84 \\
1.049 \\
1.020 \\
5.0 \\
67 \\
332 \\
48 \\
9.9\end{array}$ & \begin{tabular}{|l|}
5.203 \\
14.3 \\
46.0 \\
1.01 \\
1.01 \\
1.055 \\
1.024 \\
8.1 \\
86.8 \\
381.8 \\
61.6 \\
10.4
\end{tabular} & \begin{tabular}{|l|}
5.232 \\
14.3 \\
45.7 \\
1.01 \\
0.99 \\
1.055 \\
1.026 \\
7.8 \\
78.6 \\
381.6 \\
57.8 \\
10.4
\end{tabular} & $\begin{array}{l}0.38 \\
0.91 \\
\\
2.26 \\
0.10 \\
0.07 \\
0.002 \\
0.002 \\
1.53 \\
13.3 \\
12.9\end{array}$ & \begin{tabular}{|l}
0.44 \\
1.13 \\
2.64 \\
0.09 \\
0.08 \\
0.003 \\
0.003 \\
1.54 \\
11.2 \\
16.6
\end{tabular} \\
\hline
\end{tabular}

tions there are two points of major interest: $(a)$ the actual values, and $(b)$ the changes over a working day. Analysis of the latter point requires decision as to the limits of significant change. The limits selected were as follows: for red cell count, 250,000 cells per cu. mm.; for white cell count, 700 cells per cu. mm.; for hemoglobin, 0.5 gram per $100 \mathrm{cc}$; f for hematocrit, 2 per cent in reading; for specific gravity, 0.001 ; for blood sugar and serum chloride, $10 \mathrm{mgm}$. per 100 cc.; for carbon dioxide combining power, 5 volumes per cent; for serum calcium, $1 \mathrm{mgm}$. per $100 \mathrm{cc}$. These somewhat arbitrary limits were considered beyond the range of experimental
TABLE II

Distribution of controls according to blood changes over a work-period of eight hours

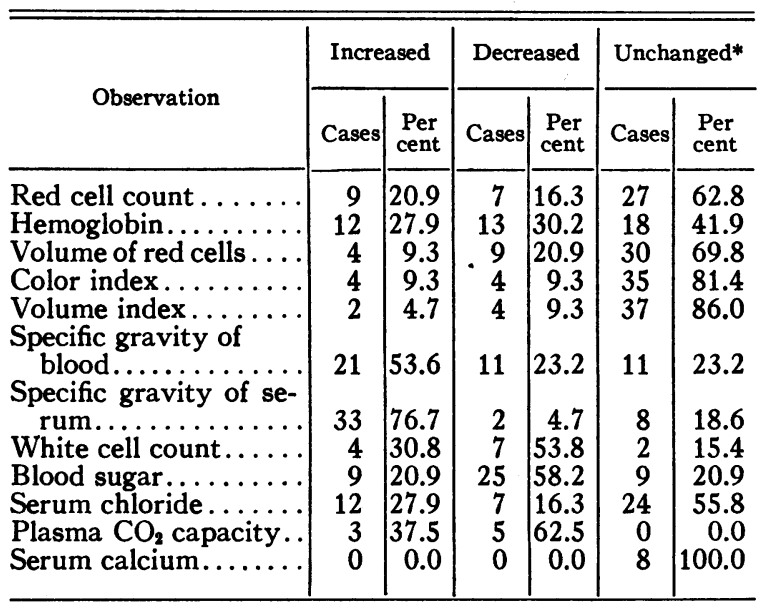

* This group includes changes which were too small to be measured unquestionably. See text for limits.

error, and proved useful for comparisons. They were applied in the compilation of Table II, which summarizes the direction of change for each blood constituent over the work-period.

Respiratory value of the blood. Red cell counts, hemoglobin estimations, hematocrit readings, and, to a certain extent, determinations of blood specific gravity are each indirect measures of the oxygen-carrying power of the blood. The results of these observations among the controls (Table I) agree in indicating the normal hemoglobin status of the group. In only one instance was the red cell count below 4.5 million cells per cu. mm., and only one hemoglobin estimation under 12 grams per $100 \mathrm{cc}$. was noted. On the other hand, 22.7 per cent of the morning and 18.1 per cent of the afternoon cell counts exceeded 5.5 million per cu. $\mathrm{mm}$. The cell count, hemoglobin, and hematocrit values were distributed rather uniformly, while blood specific gravity results grouped themselves more closely about the average, with relatively fewer values near the extremes.

The afternoon observations occupied a slightly wider range than did the morning ones in each group of determinations, but the averages and medians were almost identical. This indicates that, as a group, the values changed but little over the work-period. In individual cases, however, changes were frequently noted, and the distribu- 
tion of significant changes among the controls is summarized in Table II. The greatest stability was observed among hematocrit determinations (69.8 per cent unchanged), while the greatest number of measurable changes occurred in specific gravity (23.2 per cent unchanged). Since factors other than change of hemoglobin value influence the latter observation, close agreement between blood specific gravity and the other determinations is not to be expected. Broadly speaking, the results indicate that the respiratory value of the blood, as revealed by these particular measurements, was practically unchanged over an eight-hour shift in about half the control group, and that the remainder were about equally divided as to the direction of such change.

The magnitude of changes encountered between morning and afternoon samples was briefly as follows. In red cell count, 88.5 per cent of the control series showed changes of 0.5 million per cu. $\mathrm{mm}$. or less. In hemoglobin concentration, 95.4 per cent changed less than 1.5 grams per $100 \mathrm{cc}$, and an equal percentage showed changes in volume of packed corpuscles between plus 2 and minus 3 per cent. Changes in blood specific gravity ranged from plus 0.0078 to minus 0.006 , 69.8 per cent of the subjects changing 0.002 or less.

Color and volume index. Color index and volume index were computed according to the principles of Haden (12). The averages were close to 1.00 for both morning and afternoon series (Table I), but numerous values were beyond the accepted normal variation $( \pm 0.1)$. The minimum change considered significant was 0.1 , and few alterations exceeding this range were encountered (Table II). Hence, no important change in cellular hemoglobin concentration or in cell volume could be predicated for the great majority of the control subjects.

Specific gravity of blood and serum. The specific gravity of blood in the control group was between 1.050 and 1.060 in the morning series, and between 1.049 and 1.063 in the afternoon. The average and median for both series were 1.055. Despite the consistency of these results as a group, 53.6 per cent of the controls showed a measurable increase of blood specific gravity between morning and afternoon samples, while 23.2 per cent showed a decrease. Exact interpretation of such changes is difficult because several factors influence the specific gravity of whole blood.

The results of determinations of serum gravity were much more striking, both collectively and individually. A distinct upward shift in the afternoon values was indicated not only by the distribution but by the averages. Furthermore, 76.7 per cent of individuals showed an increase in serum gravity of 0.001 or more, the maximum increase being 0.008 . In only 2 instances ( 4.7 per cent) was the specific gravity of the serum definitely lower in the afternoon than in the morning sample. The average changes were plus 0.002 and minus 0.0006 .

Since serum is the component predominantly affected by concentration or dilution of blood, the authors feel that specific gravity of serum is a delicate qualitative index of change in blood volume. Such a view is supported indirectly by the observations of Talbott (5) who interprets the increase in serum protein associated with heat cramps as evidence of anhydremia. It is highly probable, therefore, that some degree of blood concentration occurred in about three-fourths of the control subjects during the work-period.

White cell count. The white cell count was studied in but 13 control subjects. Morning and afternoon observations occupied approximately the same range, the extremes and average for the latter series being slightly the lower. Over half the controls showed a decrease in excess of 700 cells per cu. mm. between morning and afternoon samples. No significance is attached to these changes.

Blood sugar. Considered as a group, the morning determinations of blood sugar occupied the wider range, and the afternoon average was somewhat the lower (Table I). Over half (58.2 per cent) of the controls showed a decrease in excess of $10 \mathrm{mgm}$. per $100 \mathrm{cc}$., between morning and afternoon samples. The average decrease was 21 mgm. per $100 \mathrm{cc}$., the maximum being $50 \mathrm{mgm}$. Increase of $10 \mathrm{mgm}$. or more occurred in $20.9 \mathrm{per}$ cent of the subjects. The average increase was 18 mgm. per $100 \mathrm{cc}$., with a maximum of $44 \mathrm{mgm}$. Ninety-three per cent of the controls exhibited blood sugar changes between plus 30 and minus 40 mgm. per $100 \mathrm{cc}$.

Serum chloride. Serum chloride was somewhat more stable than was blood sugar. Although the 
afternoon determinations were more widely distributed than the morning, the averages for the two series were almost identical. In addition, 55.8 per cent of the controls showed changes less than $10 \mathrm{mgm}$. per $100 \mathrm{cc}$. over the eight-hour period, while 27.9 per cent showed increase and 16.3 per cent decrease beyond this limit. The maximum changes were plus 45 and minus $44 \mathrm{mgm}$. per $100 \mathrm{cc}$., and the averages were plus 12 and minus $10 \mathrm{mgm}$. per $100 \mathrm{cc}$. Eighty-six per cent of the subjects showed changes between plus and minus $20 \mathrm{mgm}$. per $100 \mathrm{cc}$.

Plasma carbon dioxide combining power. Carbon dioxide capacity of plasma was studied in only 8 control subjects. Although no abnormal values were obtained, the results suggested moderate depletion of alkali reserve over the workperiod in 62.5 per cent of the subjects.

Serum calcium. Observations on serum calcium in 8 control subjects covered identical ranges and yielded identical averages in morning and afternoon series. The maximum change noted was an increase of $0.2 \mathrm{mgm}$. per $100 \mathrm{cc}$. in one case. The consistency of the results led to early abandonment of this determination.

\section{Summary of control series}

The blood findings among the control subjects were within normal limits. The outstanding changes over an eight-hour work-period were: (a) increase in specific gravity of blood in about half the subjects; $(b)$ increase in serum specific gravity in about three-fourths of the subjects; (c) decrease in blood sugar in nearly 60 per cent of the subjects. A majority of the controls showed no significant change in red cell count, volume of red cells, color index, volume index, or serum chloride.

\section{The blood in heat sickness}

The blood findings in victims of heat sickness will be discussed according to the clinical diagnosis. Table III summarizes the averages in this manner, and allows comparison with the afternoon control averages. Table IV shows the direction of blood changes between the symptomfree and morbid state in those patients upon whom control studies were made. Table $\mathrm{V}$ gives values from an example of each clinical type of heat disorder.
TABLE III

Comparison of averages in controls and victims of heat sickness*

\begin{tabular}{|c|c|c|c|c|c|c|c|c|}
\hline \multirow{3}{*}{ Observation } & \multirow{2}{*}{\multicolumn{2}{|c|}{$\begin{array}{c}\text { Controls } \\
\text { (P.M.) }\end{array}$}} & \multicolumn{6}{|c|}{ Patients } \\
\hline & & & \multicolumn{2}{|c|}{ Cramps } & \multicolumn{2}{|c|}{ Exhaustion } & \multicolumn{2}{|c|}{ Retention } \\
\hline & & $\sigma$ & & $\sigma$ & & $\sigma$ & & $\sigma$ \\
\hline 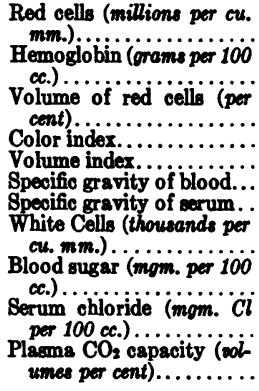 & $\begin{array}{l}5.232 \\
14.3 \\
45.7 \\
1.01 \\
0.99 \\
1.055 \\
1.026 \\
7.80 \\
78.6 \\
381.6 \\
57.8 \\
\end{array}$ & $\begin{array}{l}0.44 \\
1.13 \\
2.64 \\
0.09 \\
0.08 \\
0.003 \\
0.003 \\
1.54 \\
11.2 \\
16.6\end{array}$ & $\begin{array}{l}5.900 \\
15.5 \\
52.1 \\
0.96 \\
0.99 \\
1.063 \\
1.031 \\
11.27 \\
97.5 \\
325.3 \\
57.3 \\
\end{array}$ & $\begin{array}{l}0.90 \\
1.05 \\
5.68 \\
0.09 \\
0.07 \\
0.005 \\
0.007 \\
2.10 \\
24.8 \\
55.7\end{array}$ & $\begin{array}{l}5.700 \\
14.6 \\
48.9 \\
0.95 \\
0.99 \\
1.060 \\
1.030 \\
6.85 \\
63.6 \\
380.6 \\
41.0 \\
\end{array}$ & $\begin{array}{l}1.01 \\
0.57 \\
1.83 \\
0.13 \\
0.12 \\
0.004 \\
0.005 \\
2.18\end{array}$ & $\begin{array}{l}5.000 \\
14.8 \\
46.7 \\
1.07 \\
1.04 \\
1.057 \\
1.027 \\
8.96 \\
100.0 \\
406.7 \\
62.5\end{array}$ & $\begin{array}{l}0.22 \\
0.46 \\
1.25 \\
0.06 \\
0.06 \\
0.001 \\
0.002 \\
1.89\end{array}$ \\
\hline
\end{tabular}

* The symbol sigma refers to standard deviation.

Heat cramps. The highest individual values and the highest averages for red cell count, hemoglobin, hematocrit, white cell count, and specific gravity of blood and serum occurred among victims of heat cramps. Averages for all these determinations were distinctly higher among cramp victims than among controls (Table III). In general, the individual values for these measurements were distributed in the upper half to twothirds of the control range, with 17 to 41 per cent of values above this range and none below it. Among 7 patients with cramps upon whom control tests were made, 4 to 6 showed, during symptoms, an increase in the blood constituents under discussion (Table IV). These results indicate the frequent occurrence of some degree of blood concentration among victims of heat cramps. They indicate further that such concentration need not produce blood findings of abnormal character.

Blood sugar during cramps ranged from 44 to $168 \mathrm{mgm}$. per $100 \mathrm{cc}$., the extremes for all patients, regardless of type. The average was considerably higher among cases with cramps than among controls, but 72 per cent of the determinations were in the control range. All of the patients who served also as controls showed an increase of blood sugar during symptoms, but the changes were small.

Of the chemical measurements, serum chloride 
TABLE IV

Summary of blood changes in victims of heat sickness upon whom control observations were obtained

\begin{tabular}{|c|c|c|c|c|c|c|c|}
\hline \multirow{2}{*}{ Diagnosis } & \multirow{2}{*}{ Observation } & \multicolumn{2}{|c|}{ Increased } & \multicolumn{2}{|c|}{ Decreased } & \multicolumn{2}{|c|}{ Unchanged } \\
\hline & & Cases & $\underset{\text { cent }}{\text { Per }}$ & Cases & $\begin{array}{l}\text { Per } \\
\text { cent }\end{array}$ & Cases & $\begin{array}{c}\text { Per } \\
\text { cent }\end{array}$ \\
\hline $\begin{array}{c}\text { Heat } \\
\text { oramps }\end{array}$ & 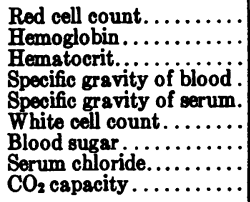 & $\begin{array}{l}5 \\
5 \\
6 \\
5 \\
4 \\
5 \\
4 \\
0 \\
1\end{array}$ & $\begin{array}{r}71.4 \\
71.4 \\
85.7 \\
71.4 \\
66.7 \\
71.4 \\
100.0 \\
0.0 \\
25.0\end{array}$ & $\begin{array}{l}0 \\
1 \\
0 \\
1 \\
0 \\
0 \\
0 \\
6 \\
2\end{array}$ & $\begin{array}{r}0.0 \\
14.3 \\
0.0 \\
14.3 \\
0.0 \\
0.0 \\
0.0 \\
85.7 \\
50.0\end{array}$ & $\begin{array}{l}2 \\
1 \\
1 \\
1 \\
1 \\
2 \\
2 \\
0 \\
1 \\
1\end{array}$ & $\begin{array}{r}28.6 \\
14.3 \\
14.3 \\
14.3 \\
33.3 \\
28.6 \\
0.0 \\
14.3 \\
25.0\end{array}$ \\
\hline $\begin{array}{c}\text { Heat } \\
\text { exhaustion }\end{array}$ & 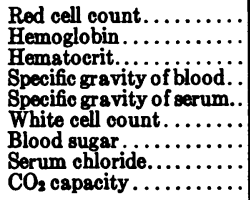 & $\begin{array}{l}2 \\
1 \\
1 \\
2 \\
1 \\
1 \\
0 \\
0\end{array}$ & \begin{tabular}{|r|}
$\mathbf{6 6 . 7}$ \\
33.3 \\
33.3 \\
66.7 \\
$\mathbf{3 3 . 3}$ \\
0.0 \\
0.0 \\
0.0
\end{tabular} & $\begin{array}{l}1 \\
\mathbf{0} \\
\mathbf{0} \\
\mathbf{1} \\
\mathbf{2} \\
\mathbf{1} \\
\mathbf{3} \\
\mathbf{0}\end{array}$ & $\begin{array}{r}33.3 \\
0.0 \\
0.0 \\
33.3 \\
66.7 \\
33.3 \\
100.0 \\
0.0\end{array}$ & $\begin{array}{l}0 \\
2 \\
2 \\
0 \\
0 \\
2 \\
0 \\
\mathbf{3}\end{array}$ & $\begin{array}{r}0.0 \\
66.7 \\
66.7 \\
0.0 \\
0.0 \\
66.7 \\
0.0 \\
100.0\end{array}$ \\
\hline $\begin{array}{c}\text { Heat } \\
\text { retention }\end{array}$ & 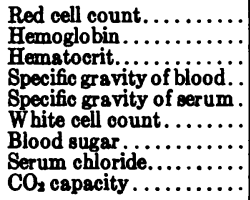 & $\begin{array}{l}\mathbf{1} \\
\mathbf{5} \\
\mathbf{1} \\
\mathbf{3} \\
\mathbf{1} \\
\mathbf{3} \\
\mathbf{1} \\
\mathbf{1} \\
\mathbf{2}\end{array}$ & \begin{tabular}{|r|}
16.7 \\
83.3 \\
16.7 \\
50.0 \\
16.7 \\
50.0 \\
25.0 \\
33.3 \\
0.0
\end{tabular} & $\begin{array}{l}1 \\
1 \\
0 \\
2 \\
5 \\
1 \\
1 \\
0 \\
1 \\
0\end{array}$ & $\begin{array}{r}16.7 \\
16.7 \\
0.0 \\
33.3 \\
83.3 \\
16.7 \\
0.0 \\
16.7 \\
0.0\end{array}$ & $\begin{array}{l}4 \\
0 \\
\mathbf{5} \\
1 \\
\mathbf{1} \\
\mathbf{2} \\
\mathbf{3} \\
\mathbf{3} \\
\mathbf{3}\end{array}$ & $\begin{array}{r}66.6 \\
0.0 \\
83.3 \\
16.7 \\
0.0 \\
33.3 \\
75.0 \\
50.0 \\
100.0\end{array}$ \\
\hline
\end{tabular}

proved most significant. Not only was the average distinctly lower among cramp patients than among controls, but 88 per cent of the patients showed values below the control average, and 35 per cent were below the lowest control figure obtained. Of 7 patients who were studied also as controls, 6 showed, during symptoms, a decrease in serum chloride exceeding $18 \mathrm{mgm}$. per $100 \mathrm{cc}$., the maximum decrease being $157 \mathrm{mgm}$. It is apparent, therefore, that partial chloride depletion of the blood frequently accompanies heat cramps. However, there is no doubt that cramps of some severity may occur with a normal serum chloride. The serum chloride level need not reflect accurately the state of tissue chlorides.

Heat exhaustion. Among patients with heat exhaustion, the averages for red cell count, hematocrit, specific gravity of blood, and specific gravity of serum were significantly higher than the corresponding control averages. The range occupied by the individual values was similar to that already described for heat cramps; that is, the results in general paralleled the upper two-thirds of the control range. Values greatly exceeding the control range were exceptional in heat exhaustion. The most striking differences between controls and patients were noted in hematocrit and in spe- cific gravity readings. For each of these determinations, 83 per cent of the patients exceeded the control average. These results indicate the frequent occurrence of dehydration among patients with heat exhaustion. The scarcity of extremely high values suggests that such dehydration was not as severe as that often accompanying cramps.

The blood sugar in heat exhaustion was below the control average in 67 per cent of the patients, though all values were in the control range. The average among patients was $63.6 \mathrm{mgm}$. per 100 cc., while the control average was $78.6 \mathrm{mgm}$. per 100 cc. Furthermore, all cases upon whom control studies were made showed decrease of this blood constituent in excess of $13 \mathrm{mgm}$. per $100 \mathrm{cc}$.

TABLE $\mathbf{V}$

Examples from various groups studied

\begin{tabular}{|c|c|c|c|c|c|c|c|c|}
\hline \multirow{2}{*}{ Obeervation } & \multicolumn{2}{|c|}{$\begin{array}{l}\text { Case 45 } \\
\text { Normal }\end{array}$} & \multicolumn{2}{|c|}{$\begin{array}{l}\text { Case } 53 \\
\text { Cramps }\end{array}$} & \multicolumn{2}{|c|}{$\begin{array}{c}\text { Case 50 } \\
\text { Exhaustion }\end{array}$} & \multicolumn{2}{|c|}{$\begin{array}{c}\text { Case 54 } \\
\text { Retention }\end{array}$} \\
\hline & A.M. & P.M. & Con- & $\begin{array}{l}\text { Symp- } \\
\text { toms }\end{array}$ & $\begin{array}{c}\text { Con- } \\
\text { trol }\end{array}$ & $\begin{array}{l}\text { Symp- } \\
\text { toms }\end{array}$ & $\begin{array}{c}\text { Con- } \\
\text { trol }\end{array}$ & $\begin{array}{l}\text { Symp- } \\
\text { toms }\end{array}$ \\
\hline 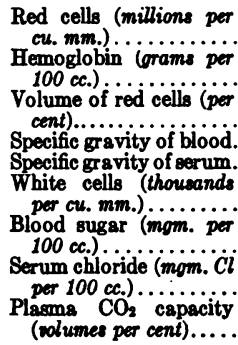 & $\begin{array}{l}5.0 \\
15.2 \\
49.5 \\
1.060 \\
1.028 \\
10.2 \\
134 \\
396 \\
76\end{array}$ & \begin{tabular}{|l}
5.2 \\
15.2 \\
49.0 \\
1.063 \\
1.032 \\
8.9 \\
102 \\
388 \\
52
\end{tabular} & \begin{tabular}{|l|}
5.0 \\
14.4 \\
50.0 \\
1.058 \\
1.034 \\
9.8 \\
89 \\
332
\end{tabular} & $\begin{array}{l}8.2 \\
17.4 \\
66.0 \\
1.072 \\
1.042 \\
18.2 \\
96 \\
198 \\
62\end{array}$ & \begin{tabular}{|l|}
5.8 \\
13.5 \\
47.0 \\
1.053 \\
1.028 \\
5.0 \\
68 \\
398
\end{tabular} & \begin{tabular}{|l}
5.1 \\
15.0 \\
48.5 \\
1.059 \\
1.029 \\
5.2 \\
44 \\
392
\end{tabular} & \begin{tabular}{|l}
4.9 \\
14.3 \\
47.5 \\
1.058 \\
1.027 \\
7.7 \\
82 \\
392 \\
62
\end{tabular} & \begin{tabular}{|l}
5.0 \\
14.9 \\
46.0 \\
1.058 \\
1.030 \\
9.2 \\
100 \\
426 \\
58
\end{tabular} \\
\hline
\end{tabular}

Plasma carbon dioxide combining power was determined for 4 patients. In each case, the result was below the lowest value encountered among controls. The averages were 41 volumes per cent for victims suffering from exhaustion and $\mathbf{5 7 . 8}$ volumes per cent for controls.

Heat retention. The blood findings in heat retention showed no important deviations from the pattern of the controls. Although the averages (Table III) for nearly all blood constituents examined were higher than the corresponding control figures, the difference in averages was significant, from a statistical viewpoint, only in the case of serum chloride, which was consistently high (above $400 \mathrm{mgm}$. per $100 \mathrm{cc}$.) in this type of patient. For all other measurements, the distribution of values failed to suggest real differences between controls and patients. 


\section{SUMMARY}

1. Red cell count, hemoglobin, per cent volume of red cells, color index, volume index, specific gravity of blood and serum, white cell count, blood sugar, serum chloride, plasma carbon dioxide combining power, and serum calcium were studied in (a) a series of symptom-free workmen exposed to high environmental temperatures, and (b) a series of patients presenting symptoms attributable to such exposure. In the control group, changes in these blood constituents over a workperiod of eight hours were measured. Control values were compared with those obtained in victims of heat sickness.

2. The results indicated (a) dehydration and (b) decrease of blood sugar over the work-period in a majority of controls.

3. The most definite blood alterations encountered among victims of heat sickness were as follows: $(a)$ in heat cramps, tendency to blood concentration and decrease of serum chloride, the greatest deviations from the controls appearing in this group; $(b)$ in heat exhaustion, tendency to blood concentration, decrease in blood sugar, and lowering of alkali reserve; $(c)$ in heat retention, consistently high normal serum chloride.

The authors gratefully acknowledge the cooperation and assistance of Drs. M. W. Heilman, W. O. Sherman, C. C. Guthrie, W. S. McEllroy, and T. K. Kruse, and the helpfulness of officials and employees of the companies directly involved in this study.

\section{BIBLIOGRAPHY}

1. Hall, W. W., and Wakefield, E. G., A study of experimental heat stroke. J. A. M. A., 1927, 89, 177.

2. Bock, A. V., and Dill, D. B., A résumé of some physiological reactions to high external temperature. New England J. Med., 1933, 209, 442.

3. Talbott, J. H., and Michelsen, J., Heat cramps. A clinical and chemical study. J. Clin. Invest., 1933, $12,533$.

4. Heilman, M. W., and Montgomery, E. S., Heat disease: A clinical and laboratory study. J. Indust. Hyg. and Toxicol., 1936, 18, 651.

5. Talbott, J. H., Heat cramps. Medicine, 1935, 14, 323.

6. Guthrie, C. C., Unpublished.

7. Barbour, H. G., and Hamilton, W. F., Blood specific gravity: Its significance and a new method for its determination. Am. J. Physiol., 1924, 69, 654.

8. Folin, O., Laboratory Manual of Biological Chemistry. Appleton Century, New York, 1934, 5th ed., p. 301 .

9. Whitehorn, J. C., Simplified method for the determination of chlorides in blood or plasma. J. Biol. Chem., 1920-21, 45, 449.

10. Peters, J. P., and Van Slyke, D. D., Quantitative Clinical Chemistry. Vol. II. Methods. Williams and Wilkins Co., Baltimore, 1932, p. 245.

11. Clark, E. P., and Collip, J. B., A study of the Tisdall method for the determination of blood serum calcium with a suggested modification. J. Biol. Chem., 1925, 63, 461.

12. Haden, R. L., The technique of a blood examination. Cleveland Clin. Quart., 1936, 3, 141. 